\title{
Cost Analysis of Deploying Femtocells in Speed Trains in Nigeria to Improve Indoor Coverage and Capacity of LTE Network
}

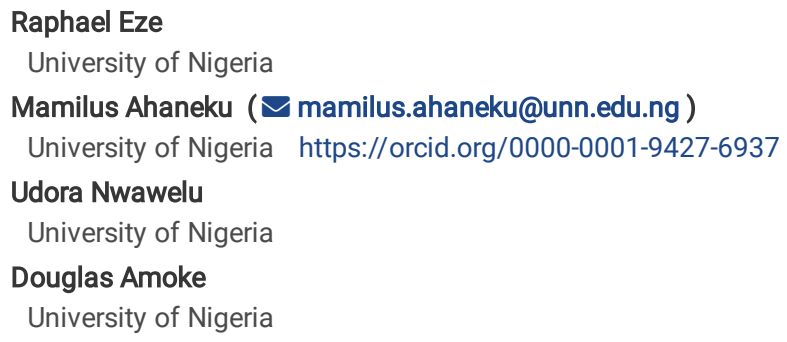

\section{Research Article}

Keywords: Net Present Value, Internal Rate of Return, Long Term Evolution, Femtocells, Sensitivity analysis

Posted Date: September 27th, 2021

DOI: https://doi.org/10.21203/rs.3.rs-854185/v1

License: () (1) This work is licensed under a Creative Commons Attribution 4.0 International License. Read Full License 


\section{Abstract}

The cost analysis of deployment of femtocells in speed trains along Abuja-Kaduna standard gauge railway line to improve the coverage and capacity of Long Term Evolution (LTE) network for 5000 commuters using that route daily is presented in this paper. Additional cost will include the cost of femtocells procurement, license, installation, backhaul, operation \& maintenance. The cost analysis is carried out using techno-economic model to determine the business viability of embarking on such a project by LTE network providers in Nigeria. The estimated capital expenditure (CAPEX) and operating expenditure (OPEX) as well as the projected revenues accrues from this project form the cash outflows and cash inflows are used to simulate the net present value (NPV) and internal rate of return (IRR) in MS Excel environment on a discount rate and tax rate of $22 \%$, and $30 \%$, respectively to determine the feasibility of the investment. The results of their NPV values which are positive show that the macro-femtocell arrangement in speed train plying Abuja-Kaduna railway route is cost effective for a life time of 10 years and is feasible up to an IRR $53 \%$ which exceeds the estimated discount rate of $22 \%$. The value of the payback period indicates that it will not take long for any LTE network provider in Nigeria to recover their investment. The result of the NPV sensitivity analysis shows how various cost and non-cost parameters affect the cost-effectiveness of such investment.

\section{Introduction}

The growing insecurity along Abuja-Kaduna high way has prompted many travelers using this highway to switch to Abuja-Kaduna standard gauge railway line as an alternative means of transportation. According to [1], 5000 commuters are using the route daily. This railway route which is about $186 \mathrm{~km}$ with nine standard stations crossed many communities and towns from Abuja to Kaduna. The LTE network providers in Nigeria can take advantage of this human traffic and make LTE network available for these commuters. LTE network itself suffers in building penetration losses (BPL) which reduce network coverage and capacity thereby making it difficult for these commuters to access the LTE network. To address this problem, the use of macro-femtocell technique which has been proposed by many researchers is needed. The use of macro-femtocell technique will introduce additional cost to providing LTE network to these commuters. The cost effectiveness of deploying these femtocells to speed train plying Abuja-Kaduna standard gauge railway line so that commuters can access LTE network is investigated in this work using techno-economic model. This model has been proposed by many researchers as a veritable tool for analyzing the feasibility of investing in a given technology as in [2ه10]. Techno-economic modeling (TEM) is used to combine research and development (R\&D), engineering, and business which can help businesses to have the knowledge of the factors that affect the profitability of their investments on technology [11]. A lot of papers have been published on joint macro-cell and femtocell networks. While majority of these papers pay attention to finding solutions to femtocell technical issues, like interference and handoff management [12囚14], others focus on using techno-economic model to determine the economic gains of deploying femtocells in LTE network in stationary structures such as tall buildings (towers), large offices and stadia [2-10]. However, no previous research has been done to study the cost of macro-femtocell arrangement in speed trains in Nigeria context. The objectives of this work are to check cost effectiveness of deployment of femtocells to already existing macro-cells in LTE network in speed trains plying Abuja-Kaduna standard gauge railway line and to perform sensitivity analysis on this cost effectiveness in order to determine how it is affected by various input parameters. The cost effectiveness is determined by the value of the Net Present Value (NPV) whose value can be negative, zero or positive as the case may be.

\section{Theoretical Background}

\subsection{Femtocells and Femtocell Access Point (FAP)}

Femtocell is a cellular base station which is small and has low power. It can cover smaller distance and is specifically made for use in in homes and small business areas [17]. A femtocell makes it possible for those that provide mobile network to increase indoor coverage or make it possible for those at the cell edge to have access to network. Apart from increasing coverage, femtocell has the ability to increase network capacity. It helps to offload traffic from macro cell.

\subsection{Abuja-Kaduna Railway Line}

Abuja-Kaduna standard gauge railway started operations in July 2016. Within two years of its operation it had provided service for about one million commuters and created about six hundred direct employments reported by Nigeria Railways Corporation (NRC) [18]. The focus of this research work is on business feasibility of deploying femtocells in speed train in Nigeria in order to improve LTE network for commuters using this means of transportation. AbujaKaduna Standard gauge railway line is used as a case study for the following reasons; It is the only most effective functional standard railway line in Nigeria offering services to over 1.5 million passengers so far (as of April 18, 2019) [19] and carrying an average of 2000 commuters daily from Abuja to Kaduna and vice versa. It is also Safer, secure, and affordable.

\subsection{Techno-economic Model}

Techno-economic model (TEM) is a tool that is used by investors in technology to determine the business viability of their investments. It contains elements of engineering and economics, and helps investors to have a better understanding of the ingredients that influence the viability of their technological investments [11]. The field of telecommunication uses bottom-up models as its techno economic analysis. This model was adopted because it is comprehensive, and helps to pinpoint inputs, outputs and function models. It supplies all the main elements of economics and engineering for the calculation of NPV [10]. The two most common platforms for TEM are Spreadsheet software and process simulation software. These two are the commonly used software for technoeconomic models. Although each has its own usefulness, MS Excel software was used in this work. TEM is shown in Fig. 1.

From this design, there are some elements that can be analyzed to get a truly comprehensive techno-economic model. They are CAPEX, OPEX, NPV, IRR and PBP. 


\section{Research Methods}

This work is on the cost effectiveness of deploying femtocells to rail mass-transit in Nigeria in order to enhance the capacity and coverage of LTE network using Abuja-Kaduna standard gauge light rail trains as a case study. It is assumed that there are already existing macro-cells covering this route, but due to vehicular penetration loss which is always an issue with radio signal, these cells are not able to provide enough capacity and coverage for LTE users plying this route. Techno-economic model used in cost analysis is a bottom up approach and data collected will be simulated on an MS Excel environment. These data include CAPEX, OPEX and expected revenues accruing from such an investment. The values so far calculated will be simulated in MS Excel environment to determine the NPV and IRR values which will be used to determine the feasibility of such an investment.

\subsection{Scenario Description}

Passenger trains plying Abuja-Kaduna standard gauge light rail is considered. The air conditioned passenger trains can carry up to 5,000 commuters according to [1]. Femtocells have to be deployed in these trains in order to provide coverage and capacity for these 5000 commuters. According to Nigeria minister of transportation, as quoted in [20], four coaches can carry up to 380 passengers. If we make provisions for at least 5000 passengers, we will be deploying femtocells in about 53 coaches. Fig. 2 shows the architecture of such deployment.

\subsection{User Demand}

Active users (user demand) are usually computed using the internal data of the particular company according to [22]. The method of determining the number of active users is exclusive to each company, and the specific details are not shared by many companies [23]. Some companies alter their computation method over time [22]. Therefore, the number of monthly active users is based on assumption with reference to previous statistics.

Most LTE network providers in Nigeria offer a monthly data rate of about $15 \mathrm{~Gb}$ [24-25]. Assuming an average demand of $10 \mathrm{~Gb}$ per user per month, then the average user data rate using 2 busy hours per day is $397.7 \mathrm{Kbps}$. Assume $80 \%$ of the 5000 commuters have access to the LTE network then their total data demand is $1.5908 \mathrm{Gbps}$. Since it is not possible that all the subscribers will be active at the busy hours, $70 \%$ of the total demand which corresponds to $1.11356 \mathrm{Gbps}$ is chosen for wireless usage. LTE network has a peak data rate of 300Mbps for downlink and while the uplink is 75 Mbps [26][27] . Femtocell is assumed to be $100 \%$ since LTE network users inside the coaches of the trains are meant to seamlessly access a femtocell because interference is assumed to be reduced based on the methods suggested in [12]. This means that every other things being equal, these standard peak rates can be achieved, but this is not the case due average sector throughput which is as a result of many usres trying to access the LTE network at peak period. Since LTE network supports terminals that have speed up to $350 \mathrm{~km} / \mathrm{h}$ or $500 \mathrm{~km} / \mathrm{h}$ which is a function of the frequency band, the download speed and upload speed will be different (slower) from fixed terminals. Therefore a minimum throughput of $2 \mathrm{Mbps}$ is assummed for a vehicle moving with a speed between $150 \mathrm{~km} / \mathrm{h}$ and $250 \mathrm{~km} / \mathrm{h}$ which is the speed of the train plying Abuja-Kaduna standard gauge railway [1].

\subsection{Coverage and Capacity of Radio Access Network}

Abuja-Kaduna standard gauge rail line covers a distance of $186 \mathrm{~km}$ with a total of nine railway stations according to [28]. Therefore, in order to meet the user demand in terms of coverage and capacity a good number of eNodeBs are needed. We assumed that at least each station has a base station (BS) with each BS having a total of three sectors. Each sector is allocated a bandwith of $10 \mathrm{MHz}$ at a frequency band of $800 \mathrm{MHz}$. A sector with a channel width of $10 \mathrm{MHz}$ has Resource Block (RB) of 50 and 600 subcarriers. The spectral efficiency and the throughput of the downlink (DL) and uplink (UL) can be calculated like thus as in [26] using 64-QAM mdulation scheme:

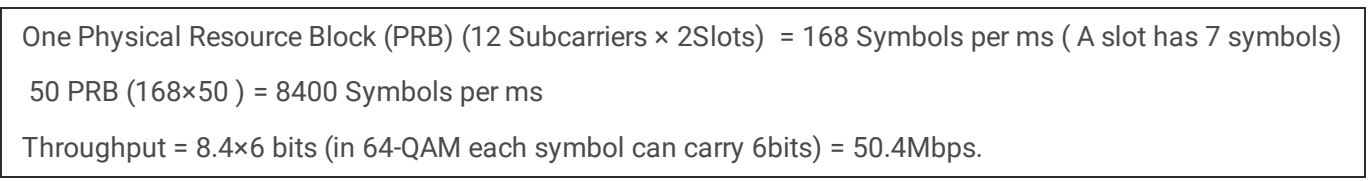

Using $2 \times 2$ Multiple Imput Multiple Output (MIMO) antenna for the downlink, this throughput is doubled so that a maxmum throughput is $100.8 \mathrm{Mbps}$. In LTE system, a fraction of this bandwidth usually $25 \%$ is dedicated for controlling and signalling according to [26]. Therefore, the downlink effective throughput is $75 \%$ of the maximum throughput which is $75.6 \mathrm{Mbps}$ or approximately $75 \mathrm{Mbps}$. For the uplink no multiple input multiple output(MIM0) antenna is required because there is only one transmit chain at User Equipment (UE) [27]. Therefore, the effective throughput for uplink is $37.8 \mathrm{Mbps}$. The Spectral Efficiency is the effective throughput divided by channel bandwidth. Therefore, the Downlink and Uplink Spectral Efficiencies are $7.56 \mathrm{bps} / \mathrm{Hz}$ and $3.78 \mathrm{bps} / \mathrm{Hz}$, respectively. The most important factor during network design is the average sector throughput which is the practical measure of the capacity of a sector serving network users in a given location [27]. This average sector throughput is effected by a number of factors such as pathloss, the number of simultaneous users, mobility, indoor/outdoor coverage, tower and antenna heights and the types of user equipments (UEs) being used on the network. With the knowledge this throughput, operators can have good understanding of their capital and operating costs, ensuring better dimensioning activity and network profitability [27]. With the above scenario, the average demands in terms of data can be met without undue interference from co-channel and adjacent channel operations which will result in performance degradation according to [27, 29-30]. To deal with this degradation femtocell solution is employed. For femocell deployment, we assumed access points using a spectrum of $5 \mathrm{MHz}$ and a throughput capacity of $10 \mathrm{Mbps}$ to enable us meet the user data demand.

\subsection{Network Dimensioning}

The network dimensioning in this work is based one evolved Node Bs (eNodeBs) and femtocells. The eNodeBs are dimensioned to meet the average user demand in terms of the busy hour data rate of $397.7 \mathrm{Kbps}$. The dimensioning of eNodeB takes into consideration the average sector throughput which is a function of channel bandwidth, antenna system and the error rate coding [31]. We assumed a sector of channel width of $10 \mathrm{MHz}$ and $2 \times 2 \mathrm{MIMO}$ antenna. The 
peak download throughput for all LTE network providers in Nigeria is shown in [32]. Assuming the average of all of them which is approximately 58.9 Mbps, based on the calculation of the number of users supported in a site with three sectors per site or eNodeB using $70 \%$ penetration.

Downlink Cell Average throughput or Capacity $\mathrm{C}=58.9 \mathrm{Mbps} /$ sector [32]

Designed Downlink Cell Loading or Penetration $\mathrm{P}=70 \%$

Designed Downlink Cell capacity or Throughput $\mathrm{T}=\mathrm{CP}=41.23 \mathrm{Mbps}$

Peak to Average Ratio $\mathrm{R}=10 \%$

Average Downlink Busy Hour Throughput/user $\mathrm{H}=397.7 \mathrm{Kbps}$

Number of Sectors per site $S=3$ sectors

Number of subscribers supported per site or eNodeB, $\mathrm{N}=\mathrm{TS} /((1+\mathrm{R}) \mathrm{H})=283$ subscribers [31].

Mobilty Spectral Efficiency based on $\mathrm{C}=\mathrm{C} / \mathrm{B}=5.89 \mathrm{bps} / \mathrm{Hz}$, where $\mathrm{B}$ is the bandwidth.

Therefore the number of sites or eNodeB that can be provided so that the 5000 commuters using Abuja-Kaduna standard gauge rail line can be served = Total number of commuters/ $\mathrm{N}=18$

This is the minimum number of eNodeBs that will be provided for 5000 commuters since LTE uses frequency reuse factor of one[ 31]. These eNodeBs should be situated along the Abuja-Kaduna rail route to provide LTE network coverage for these commuters while in transit.

For femtocell deployment which is necessary for coverage capacity improvement due to vehicular penetration loss (VPL), two access methods may be employed which are; closed subscriber group (CSG) and open subscriber group (OSG). But considering the fact this work is based on speed train which is for the public, OSG access metthod will be preferable because it will reduce the cost and number of femtocells as no subscriber desires to subscribe for a femtocell for others to use [33]. Open subscriber group femtocell can serve up to 16 subscribers simultaneously or more according to [34]. Taking 16 users per femtocell the number of femtocells that will serve 5000 subscribers is approximately 313 femtocells. These will be deployed to the 53 coaches of the passenger trains plying Abuja-Kaduna standard gauge rail line.

\subsection{Cost Structure}

The cost structure used in this work is based on techno-economic model. This choice of model is based on its comprehensiveness in incorporating elements of economics and engineering and it also makes way for identifying inputs and outputs [10]. The inputs to this model are:

- APEX

- OPEX

- Revenue

The outputs in this model are:

- Net present value (NPV)

- Internal rate of return (IRR)

- Payback period (PBP)

The parameters for the calculations of NPV and IRR are available in techno-economic model precisely in the MS Excel package. The flow diagram for technoeconomic implementation in this project is shown in Fig. 3.

\subsubsection{Capital expenditure (CAPEX)}

The CAPEX will be based on the assumption that there is already existing LTE network which could not provide network coverage and capacity for the train commuters plying Abuja-Kaduna rail line due to in-building penetration loss and femtocells are to be deployed to fill this gap. Therefore, the cost of LTE core network and spectrum license will not be included. The following CAPEX will be considered in this work: The cost of purchase of femtocells, the cost of installation of femtocells, the cost of backhaul for femtocells and the cost of site leasing.

According to Wade Sarver, Service Solution Manager at Nokia (2011-present) [35] the price of small cell can run from $\$ 2000$ and more while installation and wireless backhaul cost are $\$ 1000$ and $\$ 1000$ respectively as at July, 2018. The CAPEX of a femtocell according to [2] is $€ 1000$.This CAPEX is based on the following cost elements: Access point equipment, planning \& installation, transmission and share of the AP controller and management system. In [16], the CAPEX and OPEX for Femto Base Station (FBS) are $€ 1100$ and $€ 500$ respectively. Based on the following CAPEX, we assume FBS CAPEX to be $\$ 1500$ which includes Procurement cost, installation cost and cost of backhaul.

\subsubsection{Operational expenditure (OPEX)}


The OPEX considered in this work are operational, maintenance, marketing and administrative cost. The OPEX estimate is $\$ 500$ annually per FBS and is based on the OPEX given in [2] [16] and [35]. The technical lifetime of this device is put at 10 years, so that the NPV and IRR calculations will be based on this lifetime. The CAPEX and OPEX will form the cash outflows for the deployment of femtocells to an already existing LTE network along Abuja-Kaduna railway line in order to provide access and coverage for 5000 commuters plying that route.

The cost model used in this research work is the one used in [8] and [9]. The CAPEX and OPEX of the network elements are given as follows:

$$
\begin{aligned}
& \operatorname{CAPEX}^{(i)}=\sum_{j} \mathrm{M}_{j}^{(i)} \mathrm{c}_{j}^{\text {capex }}\left(1+\mathrm{p}_{j}^{\text {capex }}\right)^{\mathrm{i}-1} \\
& \mathrm{OPEX}^{(\mathrm{i})}=\sum_{\mathrm{j}} \mathrm{N}_{j}^{(\mathrm{i})} \mathrm{c}_{j}^{\text {opex }}\left(1+\mathrm{p}_{\mathrm{j}}^{\text {opex }}\right)^{\mathrm{i}-1}
\end{aligned}
$$

where $j$ represents each network element considered such as FBS, spectrum license, backhaul etc, $N_{j}{ }^{(i)}$ is the number of elements of type $j$ operated in year $i$, $M_{j}^{(i)}$ is the number of elements of type $j$ bought in year $i, C_{j}^{\text {capex }}$ and $C_{j}^{o p e x}$ are the per-unit investment and operating cost respectively for each element of type $j$ inY1 while $P_{j}^{\text {capex }}$ and $P_{j}^{\text {opex }}$ are the yearly price trends.

The sum of equation (1) and equation (2) can be denoted by Co, where Co can be regarded as the initial cash flow and is one of the inputs to eqn 3.

\subsubsection{Revenue}

The revenue will be forecast on average revenue per user (ARPU). This ARPU will include each user's monthly data consumption, average monthly voice calls, SMS and other services such as info news and music used as ring tone, and the cost of LTE SIM card. We chose the monthly charge because it is easy to estimate. We pegged the average monthly data consumption rate at $10 \mathrm{~Gb}$ which is the value used in my network dimensioning. This is because subscribers tend to use data more in an environment where access to a network is seamless which deployment of femtocells to LTE network will provide to indoor users of LTE network. We assume 2000 NGN as ARPU per month for voice call, SMS and order services while ARPU for 10Gb monthly data consumption is estimated to be 3500 according to [24区25] NGN which is the monthly data price for most LTE network providers in Nigeria. The total annual revenue forms the annual cash inflows used in the computation of NPV and IRR to determine the economic feasibility of deploying femtocells to already existing LTE network along Abuja-Kaduna railway line for 5000 commuters plying that route.

\section{The discount rate}

The discount rate which is also referred as opportunity cost of capital is the rate of interest used to find out the anticipated or present value of future cash flows [36]. The discount rate is $10 \%$ by default, although in this work we used a discount rate of $22 \%$ based on the Central Bank of Nigeria (CBN) current interest rate of $13.5 \%$ [37] as our benchmark.

\subsubsection{Net Present Value (NPV) and Internal Rate of Return (IRR)}

The NPV and the IRR are economic tools used to carry out sensitivity analysis on several parameters such as CAPEX, OPEX and revenues based on discounted rate. Their values are used to determine the viability of investing in a particular business venture. If the NPV is positive the project is viable, and it shows that the investment is cost effective considering the time value of money which is expressed by the discount rate. IRR is the discount rate that makes the NPV zero. If the IRR is greater than the discount rate used in the economic analysis, in this case $22 \%$, then the investment is cost effective. NPV and IRR are calculated using these mathematical expressions of Eqn 3:

$$
\mathrm{NPV}=\sum_{\mathrm{t}=0}^{\mathrm{N}} \frac{\mathrm{C}_{\mathrm{t}}}{(1+\mathrm{r})^{\mathrm{t}}}+\mathrm{C}_{0}
$$

Where $C_{t}$ is the cash flow each period $t, C_{0}$ is initial cash flow and it is negative, $t$ is each period, $r$ is the discount rate, $\mathrm{N}$ is the total number of project life time

If NPV is zero then $r=I R R$

Fortunately, NPV and IRR can be simulated in an MS Excel environment where their functions are provided. Therefore, in this work the NPV and IRR are simulated using MS Excel.

\subsubsection{Payback Period (PBP)}

This is period when the cash balance turns positive showing that there will be a return on investment beginning from that period.

\section{Results And Analysis}

\section{$5.1 \quad$ Cash Outflows}


The cash outflows which will be used in the techno-economic analysis will comprise the CAPEX and the OPEX values of femtocell base stations (FBS). The CAPEX and the OPEX values of eNodeBs were not considered because it is assumed that these facilities were already in place but were not able to provide access for 5000 train passengers plying Abuja-Kaduna railway route in terms of coverage and capacity, and femtocells were deployed to play that role. From the dimensional analysis part of this work, it is shown that about 313 FBS are needed to ensure that these 5000 commuters at most have access to LTE network daily with each FBS serving 16 simultaneous users. Table 1 shows the total CAPEX and OPEX for these 313 FBS distributed among the 53 passenger coaches plying Abuja-Kaduna standard gauge railway line.

The above CAPEX shown in Table 1 is based on FBS procurement, installation and license and backhaul costs. The OPEX is an annualized OPEX and covers operation, maintenance, marketing and administrative costs. Table 2 presents the FBS annualized OPEX estimation.

The total cash outflow denoted by Co is given in table 3 which is the sum of the CAPEX and the average annualized OPEX.

\subsection{Cash Inflows}

The cash inflows will be based on revenues accrued from different services offered by LTE network Providers in Nigeria. Therefore, the total ARPU is given as 5500 NGN. This ARPU is multiplied by the total number of users to get the total annual revenue. $70 \%$ of the 5000 commuters were assumed to be actively using the network as it is impossible for the 5000 passengers to have access to the network during the busy hours. Table 4 shows the total for the first year and the gradual increment in subsequent years.

\subsection{Calculation of Net Present Value (NPV) and Internal Rate of Return (IRR)}

Computation of NPV and the IRR require the following parameters: cash outflows, cash inflows, project life time, discount rate, income tax (corporate tax). The tax is calculated after company's net profit. The Nigerian corporate tax is put at $30 \%$ according to [38]. Therefore, the cash inflows used in the calculation of NPV and IRR were the after tax ash inflows given in table 5

\subsection{Simulation of NPV and IRR}

The NPV and the IRR are simulated for different oriented approaches in an MS Excel environment using the following parameters:

- Net cash flows after tax as seen in table 5

- Cash out flows for each approach

- Discount rate estimated at $22 \%$ which is above the CBN interest rate benchmark of $13.5 \%$

Table 6 shows the result of these simulations.

From the results of the simulations as shown in table 6, it can be seen that NPV is positive for both approaches and that IRR value is greater than the estimated discount rate of $22 \%$. This means that the investment is feasible. Therefore, the deployment of femtocells to existing LTE network is cost effective at IRR values up to $53 \%$. Any IRR value above $53 \%$ makes the NPV value negative and consequently the project will not be feasible.

\subsection{Calculation of Pay Back Period}

It can be seen from Table 7 that it will take about 1.75 years for the LTE network providers in Nigeria to recover their investment on deploying femtocells in order to improve LTE network coverage and capacity for the 5000 commuters using the speed train on this rail line.

\subsection{NPV Sensitivity Analysis}

Sensitivity analysis helps to find out how different how different inputs process affect an output process based on a given set of assumptions [39]. By changing one input variable while others are kept constant how sensitive the output is can be evaluated. In this work, sensitivity analysis was carried out to check how various input parameters such as CAPEX, OPEX, Tax rate, number active users and so on affect the output parameter in this case the NPV value. The result is shown in a spider chart, as depicted in Fig. 4. Tax rate and OPEX sensitivities are approximately the same. This has resulted in the enveloping of the OPEX by the tax rate.

From Fig. 4, it can be observed that the input variable that the investors need to worry about most is the number of users because it impacts most on the feasibility of this investment. This is followed by the ARPU. Therefore, the service provider should ensure that it provides good quality network with an impressive quality of service (QoS) in order to encourage more users resulting in increase in ARPU.

\section{Conclusion}

The results of the techno-economic breakdown show the Net Present Value (NPV) to be positive which is $\$ 278,398,044.80$ at a discount rate of $22 \%$. This means that it is cost effective for LTE network providers in Nigeria to embark on such a project. The Internal Rate of Return (IRR) values of $53 \%$ are an indication that this investment is feasible at these discounted rates above which it will no longer be viable. From the value of the payback period which is about 1.75 years. This infers that it will not take long before investors will start having a return on their investment.

Finally, the result of the NPV sensitivity analysis shows that among the various cost and non-cost parameters, the cost effectiveness is affected most by the number of active number of users and the ARPU. The result also shows the investment is not feasible at a discount rate above the internal rate of return of $53 \%$. 
From the results of NPV and IRR values which are strong indicators of the viability of investing in this technology by LTE network providers in Nigeria, we recommend for future work the use of game theory model that will enable an LTE network provider to outsmart its competitors. Performance analysis of deployment of femtocells in speed trains along Abuja-Kaduna railway line could be carried out in order to improve indoor coverage and capacity of LTE network.

\section{Declarations}

\section{Conflict of Interest}

None declared

\section{Funding}

This research work is supported by the Intra-Africa-Reinforcing Coherence Relevance and Partnership in Computer Engineering-Africom Project (19B4061).

\section{Data Availability}

Data used in this research can be obtained from the corresponding author on reasonable request

\section{Author Contribution}

Raphael Chijioke Eze and Mamilus Aginwa Ahaneku conceptualized the study. Udora Nwabuoku Nwawelu and Douglas Amobi Amoke participated in data curation, formal analysis and manuscript drafting. All authors approved the final version of the manuscript.

\section{References}

[1] Mark, B (2016, July 25). Nigeria set to launch new high speed train this week. Face to Face Africa. Retrieved August 1, 2019 ,

from https://face2faceafrica.com/article/nigeria-set-launch-new-high-speed-trains-week

[2] Markendahl, J., Mäkitalo, Ö., \& Werding, J. (2008). Analysis of cost structure and business model options for Wireless Access Provisioning using Femtocell solutions. $19^{\text {th }}$ European Regional ITS Conference, Rome

[3] Femtoforum (2009, June 1) Femtocell business case white paper. Retrieved August 1, 2019, from www.femtoforum.org

[4] Claussen, H., Ho, L. T. W., \& Samuel, L. G. (2007). Financial analysis of a pico-cellular home network deployment. $7^{\text {th }}$ IEEE International Conference on Communication, Glasgow

[5] Loizillon, F. et al. (2002). Final results on seamless mobile IP service provision economics. Retrieved August 1, 2019, from http://wwwnrc.nokia.com/tonic

[6] Johansson, K. (2007). Cost effective deployment strategies for heterogeneous wireless networks. PhD Dissertation, Royal Institute of Technology, Stockholm

[7] Johansson, K. et al. (2004). Relation between base station characteristics and cost structure in cellular networks. $15^{\text {th }}$ International Symposium on Personal, Indoor and Mobile Radio Communications, New York

[8] Antolín, M., Josep, V., Jorge, P., Adrián, A., Ninoslav, M., \& Anders, H. M. (2011). Technoeconomic evaluation of cooperative relaying transmission techniques in OFDM cellular networks. EURASIP Journal on Advances in Signal Processing, 6, 1囚23

[9] Zoraida, F., \& Jorge Pérez. (2012). Techno-economic analysis of femtocell deployment in long term evolution networks. EURASIP Journal on Wireless Communications and Networking, 288, 1 囚15

[10] Krisnadi, I., \& Tanjung, I. K. (2017). Feasibility analysis of implementation $3 G$ macro additional sector Jabo area using techno-economic approach. IncomTech, Jurnal Telekomunikasi dan Komputer, 7, 297ه312

[11] Burk, C. (2018). Techno-economic modeling for new technology development. Retrieved August, 1, 2019, https://www.aiche.org/resources/publications/cep/2018/january/techno-economic-modeling-new-technology-development

[12] López-Pérez, D., Valcarce, A., De la Roche, G., \& Zhang, J. (2009). OFDMA femtocells: a roadmap on interference avoidance. IEEE Communication Magazine, 47, 41-48

[13] Chandrasekhar, V., Andrews, J., Gartherer, A. (2008). Femtocell networks: a survey. IEEE Communication Magazine, 47, 59-67

[14] Chowdhury, M. Z., Jang, Y. M., \& Haas, Z. J. (2010). Network Evolution and QoS Provisioning for Integrated Femtocell/Macrocell Networks. International Journal of Wireless and Mobile Networks, 2, 1 16 
[15] Claussen, H., Ho, L., \& Samuel, L. (2007). Financial analysis of a pico- cellular home network deployment. $7^{\text {th }}$ IEEE International Conference on Communications, Glasgow

[16] Smail, G., \& Weijia, J. (2017). Techno-economic analysis and prediction for the deployment of 5 G mobile network. 20th Conference on Innovations in Clouds, Internet and Networks, Paris

[17] Qualcomm Incorporated, (2011, June 3). Enterprise multi-femtocell deployment guidelines. Retrieved August, 1, 2019, from https://file:///C:/Users/Ralph/Downloads/qualcomm-research-enterprise-femtocell\%20(1).pdf

\section{[18] Algali, A (2018, August 10) Indepth: How Nigeria's Abuja-Kaduna railway is impacting lives of commuters, communities at both ends of rail corridor. Retrieved August, 1, 2019, from https://www.africannewspage.net/2018/08/10/how-abuja-kaduna- railway-is-impacting-the-lives-of-commuters-and-communities-at-both-ends- of-the-rail-corridor-in-nigeria/}

[19] Odoh, I (2019, April 21). Abuja-Kaduna railway services in high demand after 1000 days of operation. Retrieved August, 1, 2019, from https://businessday.ng/features/article/abuja-kaduna-railway-services-in-high-demand after 1000-days-of-operation

[20] Saanyol, T. (2016, July 3). FG to buy more locomotives, coaches for Abuja-Kaduna rail. Retrieved August, 1, 2019,

from https://tribuneonlineng.com/fg-buy-locomotives-coaches-abuja-kaduna-rail/

[21] Raheem, R. et al. (2014). Performance Evaluation of LTE network via Fixed/Mobile Femtocells. $28^{\text {th }}$ International Conference on Advanced Networking and Applications Workshops, United Kingdom

[22] Facebook Incorporated (2018, July 26). United States Securities and Exchange Commission. Retrieved August, 1, 2019,

from https://www.google.com/search?q=Facebook+Incorporated+\%282018\%2C+July+26\%29.+United+States+Securities+and+Exchange+Commission.

[23] Theresa, F., Henry, C. P. A., Rosenthal, D. A., \& Weitz, R. R. (2014). Socially awkward: social media companies' nonfinancial metrics can send a mixed message. Journal of Accountancy, 1, 52囚63.

[24] Mobile Telecommunication Network. (2020). MTN data plans. Retrieved August 1, 2019, https://www.mtnonline.com/personal/data/data-plans/

[25] Globacom Nigeria Limited. (2020, August 1). Glo data plans. Retrieved October 26, 2020, from https://www.gloworld.com/ng/personal/data/dataplans/

[26] Techplayon (2017, June). LTE FDD throughput calculation. Retrieved August 1, 2019, from http://www.techplayon.cm/Ite-fdd-system-capacity-andthroughput-calculation

[27] Motorola (2009, August 1). Realistic LTE performance from peak rate to subscriber experience. Retrieved August 1, 2019,

from https://pdfcoffee.com/realistic-lte-experience-whitepaper-motorola-august2009-pdf-free.html

[28] Verdict Media Limited (2014, December). Abuja-Kaduna rail line. Retrieved August 1, 2019, from https://www.railway-technology.com/projects/abujakaduna-rail-line/

[29] Claussen, H. (2007). Performance of macro- and co-channel femtocells in a hierarchical cell structure. $18^{\text {th }}$ IEEE International Symposium on Personal, Indoor and Mobile Radio Communications, Oulu 
[30] Ericsson (2008, May 9). Downlink co-existence between macro cells and adjacent channel home NodeBs. Technical Meeting, Kansas City

[31] Ayman, E. (2018, October 6). Practical Aspects of LTE Network Design and Deployment. Retrieved August 1, 2019, from

https://arxiv.org/abs/1810.02970

[32] Techeconmy (2019, December 1). (REPORT) 4G mobile network performance in Nigeria witnessed improvements in 2019. Retrieved November 10,

2020, from https://techeconomy.ng/2019/12/report-4g-mobile-network-performance-in-nigeria witnessed-improvements-in-2019/

[33] Holma, H., \& Toskala, A. (2009). LTE for UMTS-OFDMA and SC-FDMA based radio. Wiley Publishing

[34] Pakistani Telecommunication Authority (2012, November 2010). Study report on regulatory issues in femtocell (indoor) deployment strategy. Retrieved August 1, 2019, from https://www.pta.gov.pk/media/draft_femtocells_report_130313.pdf

[35] Quora (2018, January 1). How much does a 4G LTE base station CAPEX and OPEX cost. Retrieved October 8, 2019, from http//www.quora.com/Howmuch-does-a-4G-LTE-base-station-Capex-and-Opex-cost

[36] Brealey, R. A., \& Myers, S. C. (2000). Principles of corporate finance. McGraw-Hill.

[37] Central Bank of Nigeria. (2019, October 8). Money market indicators (in percentage). Retrieved October 8,

2019, https://www.cbn.gov.ng/rates/mnymktind.asp?year=2019\&m

onth $=10$

[38] Federal Inland Revenue Service. (2019, August 1). Tag: income tax payment. Retrieved October 10, 2019 , from https://www.firs.gov.ng/sites/Authoring/contentLibrary-

[39] Timo. S. (2004). Techno-economic analysis of IEEE 802.16a-based fixed wireless access networks. M.Sc. Thesis, Helsinki University of Technology, Helsinki.

\section{Tables}

Table 1 FBS CAPEX estimation

\begin{tabular}{|lccc|}
\hline & Number of FBS & CAPEX $(\$)$ & CAPEX (NGN) \\
& & & 380 NGN=\$1 \\
\hline 16 users per FBS & 313 & 469500 & 178410000 \\
\hline
\end{tabular}

Table 2 FBS annualized OPEX estimation

\begin{tabular}{|c|c|c|c|c|}
\hline Number & of year & Number of FBS (User Oriented) & OPEX(\$) & OPEX (NGN) \\
\hline Year1 & & 313 & 156500 & 59470000 \\
\hline Year2 & & 313 & 156500 & 59470000 \\
\hline Year3 & & 313 & 156500 & 59470000 \\
\hline Year4 & & 313 & 156500 & 59470000 \\
\hline Year5 & & 313 & 156500 & 59470000 \\
\hline Year6 & & 313 & 156500 & 59470000 \\
\hline Year7 & & 313 & 156500 & 59470000 \\
\hline Year8 & & 313 & 156500 & 59470000 \\
\hline Year9 & & 313 & 156500 & 59470000 \\
\hline Year10 & & 313 & 156500 & 59470000 \\
\hline Total & & & 1565000 & 594700000 \\
\hline
\end{tabular}

Table 3 FBS cash outflows 


\begin{tabular}{|c|c|c|c|}
\hline \multicolumn{4}{|c|}{ INVESTMENT } \\
\hline C & APEX (NGN) & 1 & 78410000 \\
\hline & OPEX (NGN) & & 59470000 \\
\hline C & ASH OUTFLOWS(NGN) & 2 & 37880000 \\
\hline
\end{tabular}

Table 4 Estimation of annual revenues (cash inflows) from the investment

\begin{tabular}{|c|c|c|c|}
\hline $\begin{array}{l}\text { Number of } \\
\text { years }\end{array}$ & $\begin{array}{l}\text { ARPU for data in NGN with } 3 \% \text { annual increase } \\
\text { compounding }\end{array}$ & $\begin{array}{l}\text { ARPU for other services in NGN with } 1 \% \text { annual increase } \\
\text { compounding }\end{array}$ & Total in NGN \\
\hline Income year 1 & $147,000,000.00$ & $84,000,000.00$ & $231,000,000.00$ \\
\hline Income year 2 & $151,410,000.00$ & $84,840,000.00$ & $236,250,000.00$ \\
\hline Income year 3 & $155,952,300.00$ & $85,688,400.00$ & $241,640,700.00$ \\
\hline Income year 4 & $160,630,869.00$ & $86,545,284.00$ & $247,176,153.00$ \\
\hline Income year 5 & $165,449,795.07$ & $87,410,736.84$ & $252,860,531.91$ \\
\hline Income year 6 & $170,413,288.92$ & $88,284,844.21$ & $258,698,133.13$ \\
\hline Income year 7 & $175,525,687.59$ & $89,167,692.65$ & $264,693,380.24$ \\
\hline Income year 8 & $180,791,458.22$ & $90,059,369.58$ & $270,850,827.79$ \\
\hline Income year 9 & $186,215,201.96$ & $90,959,963.27$ & $277,175,165.24$ \\
\hline $\begin{array}{l}\text { Income year } \\
10\end{array}$ & $191,801,658.02$ & $91,869,562.91$ & $283,671,220.93$ \\
\hline
\end{tabular}

Table 5 Cash flows at $30 \%$ tax

\begin{tabular}{|c|c|c|c|c|c|}
\hline \multicolumn{6}{|c|}{ Cash Flows@ @ 30\% tax } \\
\hline Year & $\begin{array}{l}\text { Revenue inflows in } \\
\text { NGN }\end{array}$ & Cash outflows in NGN & $\begin{array}{l}\text { Net cash flows before tax in } \\
\text { NGN }\end{array}$ & Tax @ 30\% in NGN & $\begin{array}{l}\text { Net cash flows after tax in } \\
\text { NGN }\end{array}$ \\
\hline 1 & $231,000,000.00$ & $59,470,000.00$ & $171,530,000.00$ & $51,459,000.00$ & $120,071,000.00$ \\
\hline 2 & $236,250,000.00$ & $59,470,000.00$ & $176,780,000.00$ & $53,034,000.00$ & $123,746,000.00$ \\
\hline 3 & $241,640,700.00$ & $59,470,000.00$ & $182,170,700.00$ & $54,651,210.00$ & $127,519,490.00$ \\
\hline 4 & $247,176,153.00$ & $59,470,000.00$ & $187,706,153.00$ & $56,311,845.90$ & $131,394,307.10$ \\
\hline 5 & $252,860,531.91$ & $59,470,000.00$ & $193,390,531.91$ & $58,017,159.57$ & $135,373,372.34$ \\
\hline 6 & $258,698,133.13$ & $59,470,000.00$ & $199,228,133.13$ & $59,768,439.94$ & $139,459,693.19$ \\
\hline 7 & $264,693,380.24$ & $59,470,000.00$ & $205,223,380.24$ & $61,567,014.07$ & $143,656,366.17$ \\
\hline 8 & $270,850,827.79$ & $59,470,000.00$ & $211,380,827.79$ & $63,414,248.34$ & $147,966,579.46$ \\
\hline 9 & $277,175,165.24$ & $59,470,000.00$ & $217,705,165.24$ & $65,311,549.57$ & $152,393,615.67$ \\
\hline 10 & $283,671,220.93$ & $59,470,000.00$ & $224,201,220.93$ & $67,260,366.28$ & $156,940,854.65$ \\
\hline
\end{tabular}

Table 6 NPV and IRR values 


\begin{tabular}{|lcllll|}
\hline \multicolumn{4}{|l|}{ Net Present Value (NPV) in NGN and Internal Rate of Return (IRR) } & & \\
\hline Year & Cash flows in NGN & Description & Discount rate & 0.22 & FEASIBLE \\
year 0 & $(237,880,000.00)$ & Investment & NPV & 278,398,044.80 & FEASIBLE \\
\hline year 1 & $120,071,000.00$ & Net cash flows after tax & IRR & $53 \%$ & FEASIBLE \\
\hline year 2 & $123,746,000.00$ & Net cash flows after tax & & \\
\hline year 3 & $127,519,490.00$ & Net cash flows after tax & & \\
\hline year 4 & $131,394,307.10$ & Net cash flows after tax & & \\
\hline year 5 & $135,373,372.34$ & Net cash flows after tax & & \\
\hline year 6 & $139,459,693.19$ & Net cash flows after tax & & \\
\hline year 7 & $143,656,366.17$ & Net cash flows after tax & & \\
\hline year 8 & $147,966,579.46$ & Net cash flows after tax & & \\
\hline year 9 & $152,393,615.67$ & Net cash flows after tax & & \\
\hline year 10 & $156,940,854.65$ & Net cash flows after tax & & \\
\hline
\end{tabular}

Table 7 Payback period

\begin{tabular}{|c|c|c|c|c|c|c|c|}
\hline \multicolumn{8}{|c|}{ Payback Period } \\
\hline & year 0 & year 1 & year 2 & year 3 & year 4 & year 5 & year 6 \\
\hline $\begin{array}{l}\text { Initial } \\
\text { Outlay }\end{array}$ & $\begin{array}{l}\text { A } \\
237,880,000.0\end{array}$ & & & & & & \\
\hline $\begin{array}{l}\text { After-tax } \\
\text { cash flows }\end{array}$ & & \#20,071,000.00 & $\# 123,746,000.00$ & $\# 127,519,490.00$ & $\# 131,394,307.10$ & \#135,373,372.34 & $\# 139,459,6$ ؟ \\
\hline $\begin{array}{l}\text { Cumulative } \\
\text { cash flow }\end{array}$ & $\begin{array}{l}\text { A } \\
-237,880,000.00\end{array}$ & \#-117,809,000.0 & $\# 5,937,000.00$ & $\# 133,456,490.00$ & $\# 264,850,797.10$ & $\# 400,224,169.44$ & $\# 539,683,86$ \\
\hline $\begin{array}{l}\text { Add a } \\
\text { fraction } \\
\text { row }\end{array}$ & - & - & -0.923850934 & 0.045184606 & 0.985840034 & 1.89912075 & $2.78598282 \subseteq$ \\
\hline $\begin{array}{l}\text { Full yrs } \\
\text { where CCF } \\
\text { is -ve }\end{array}$ & & 1 & 0 & 0 & 0 & 0 & 0 \\
\hline $\begin{array}{l}\text { Partial yrs } \\
\text { where CCF } \\
\text { is -ve }\end{array}$ & -0.923850934 & $\begin{array}{l}\text { Partial yrs where } \\
\text { CCF is -ve }\end{array}$ & & & & & \\
\hline \multirow[t]{2}{*}{$\begin{array}{l}\text { Payback } \\
\text { period }\end{array}$} & & \multicolumn{6}{|c|}{$\begin{array}{l}1.923850934 \text { Ignoring the negative } \\
\text { sign }\end{array}$} \\
\hline & & \multicolumn{6}{|c|}{1 year, 9 months, 2 days } \\
\hline
\end{tabular}

\section{Figures}




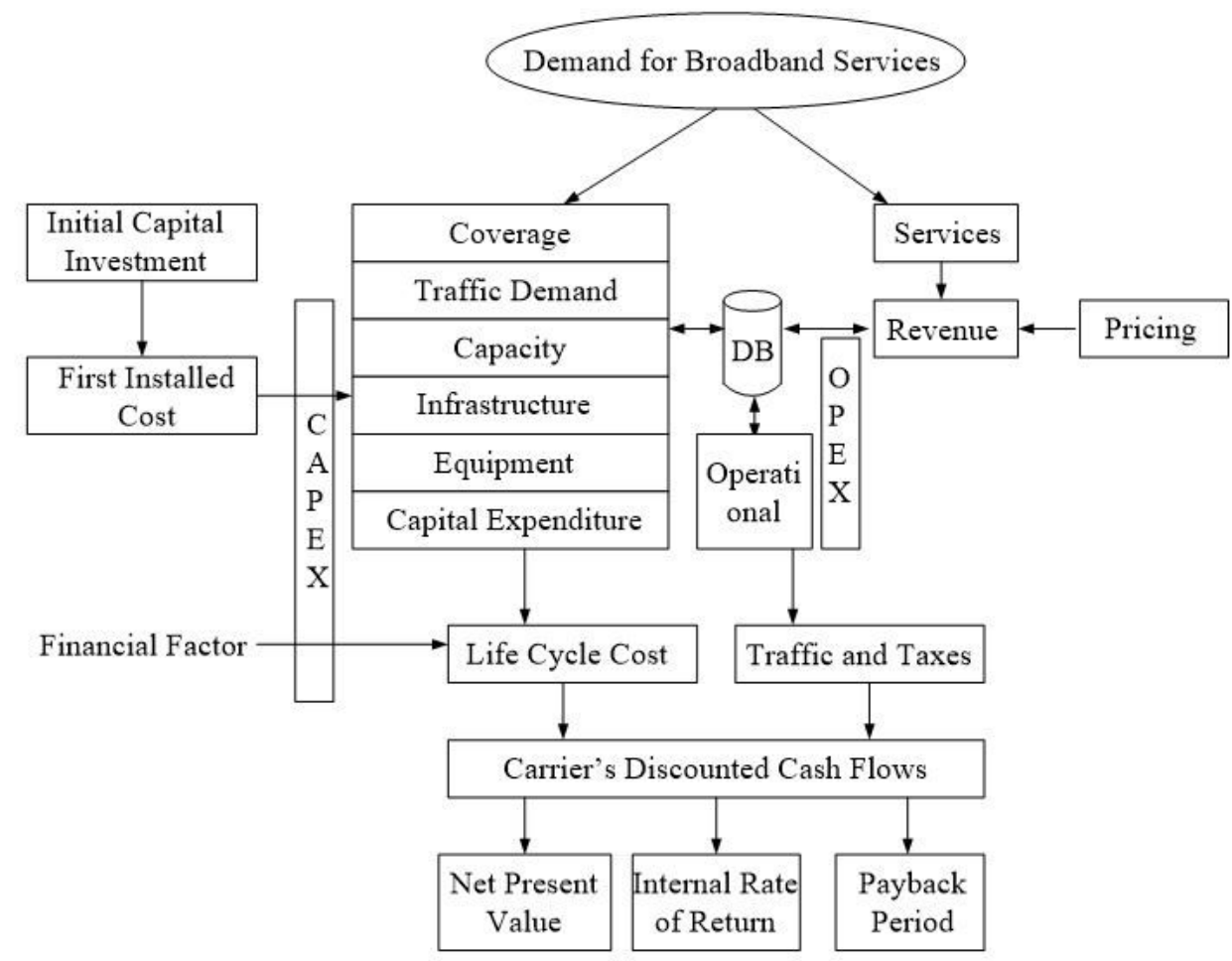

Figure 1

Techno-economic methodology and tool [10]

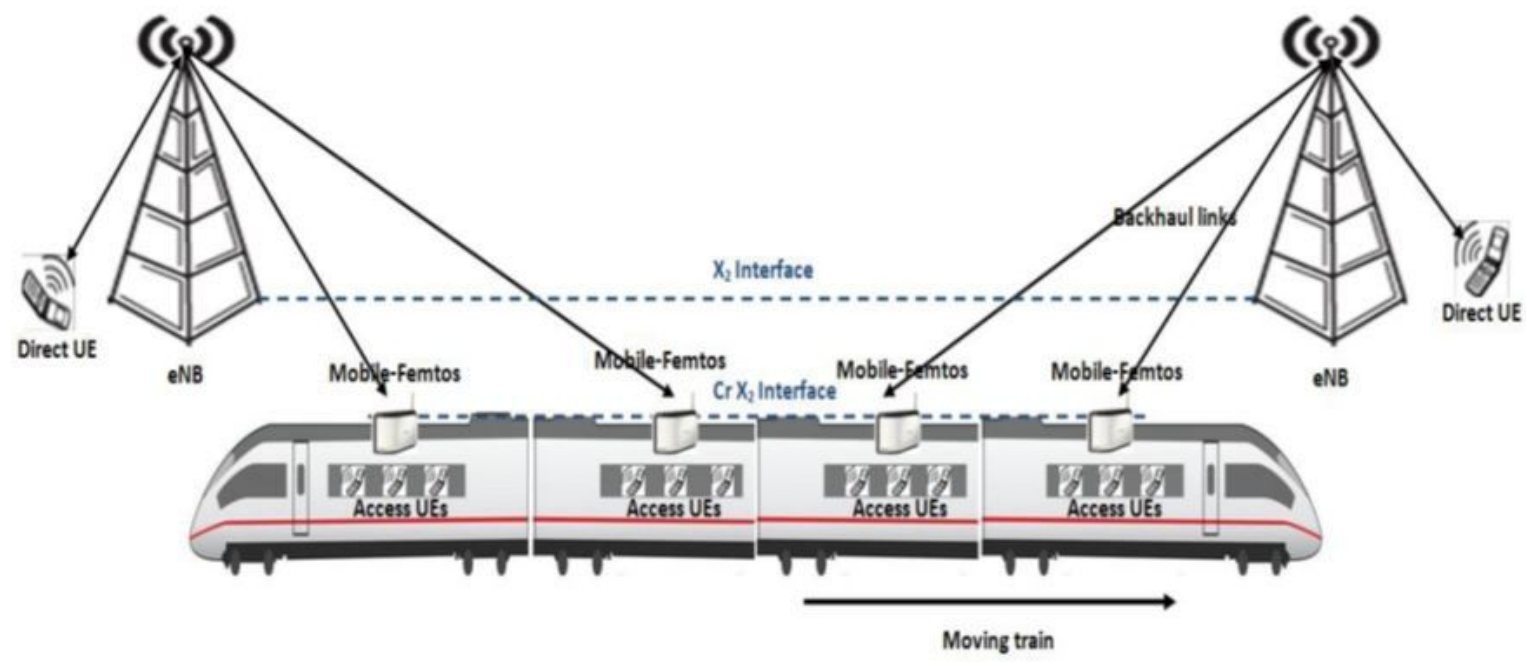

Figure 2

Architecture of macro-femtocell arrangement in speed trains [21] 


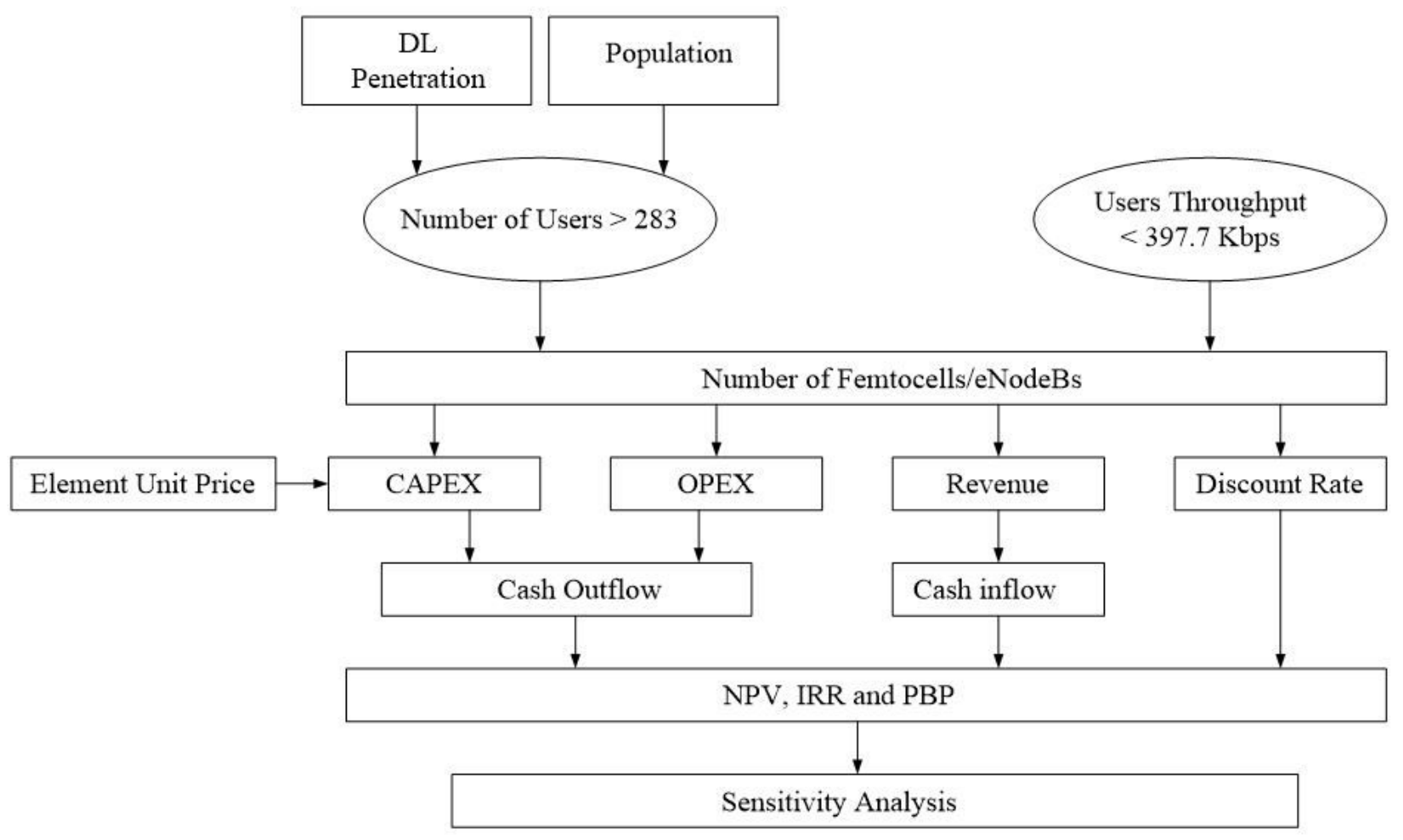

Figure 3

Flow diagram for techno-economic model implementation

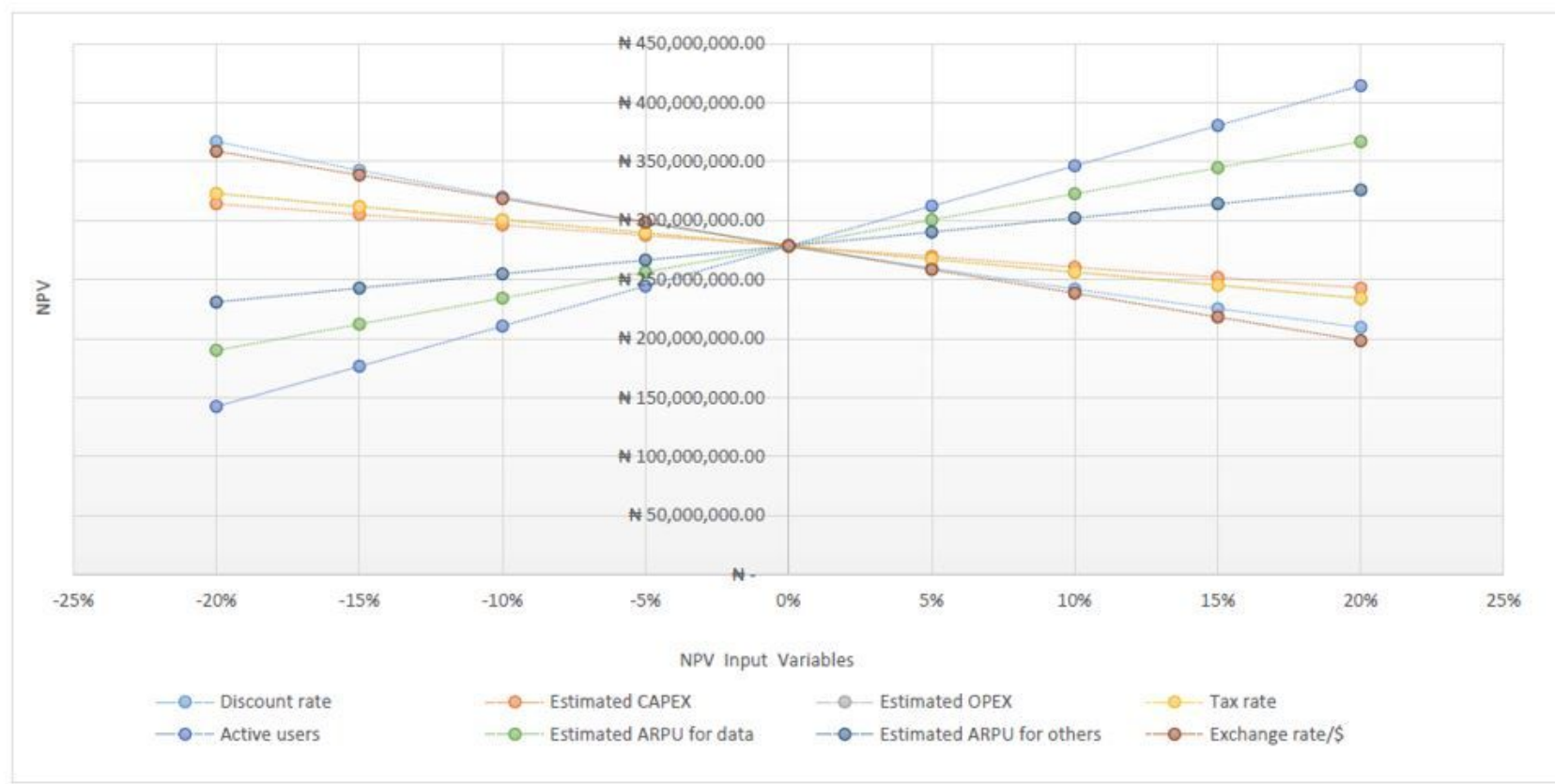

Figure 4

Spider chart for NPV sensitivity analysis 